\title{
Introduction
}

\section{Patrick S Hodge}

The idea of this book arose in the Spring of 1992 before the General Election. At that time there was much media coverage of the nationalist arguments but few voices were raised arguing the case for the continuance of the Union. While politics have moved on, the continuing economic integration and likely political development of the European Union (EU) make the structure of the United Kingdom (UK) government and the future role of the Westminster Parliament important issues for discussion. The elections of 1994 - European Parliament, local government and the Monklands by-election - have all suggested that the form of Scottish government remains a live political question.

The book comprises eight essays. It begins with three essays on economic questions which deal respectively with industry, financial institutions and the general economy. The fourth essay discusses the representation of Scottish interests in international affairs. Then one Scottish and one English historian consider from their different perspectives the background and consequences of the Union of 1707 . The seventh contribution, by a constitutional lawyer, provides a legal analysis of the British constitution. The final essay is an examination of the development of a British culture and its contribution to Scottish identity. Each of the essays argues for the continuing validity of the Union formed in 1707, although that is not to say that all the contributors subscribe to the status quo.

In sum, the first four essays suggest that independence would impose significant financial and other costs on Scotland, which would outweigh possible benefits. The last four essays call into question some of the beliefs and assumptions which underlie Scottish nationalism, and in particular, nationalist views of Scottish cultural identity.

\section{Economic Arguments}

The benefit of the Union to the Scottish economy was among the strongest arguments in its favour when the Union was negotiated. 'Trade with most ....' was the Earl of Roxburgh's contemporary judgment of the motives of the majority of the Scottish Parliamentarians in favour of the Union of 1707. In the twentieth century political pressure for constitutional change in Scotland has periodically ebbed and flowed, increasing in the latter part of the century. 
But the Scottish business community has shown no enthusiasm for devolutionary initiatives, and open hostility to Scottish independence.

The first three essays in this compilation set out economic arguments which question the material benefits to be derived from independence. These identify significant costs which may be a consequence of separation from the UK.

\section{Scottish Industry}

The benefit of free access to larger and more prosperous markets was a powerful argument in favour of the Union at the outset. It remains so. In his essay Sir Gerald Elliot, an industrialist, articulates views which are held by many in Scottish industry. First, he emphasises the need to maintain an integrated UK economy. Scottish industry is dependent on international trade because the majority of its markets is outwith Scotland. The economic integration of the UK provides opportunities for Scottish business. Networks of commercial and personal relationships have developed which transcend the boundaries of Scotland. Secondly, the consumer has benefited significantly from the existence of free trade within the UK and from the development of relatively free trade internationally. These benefits should be preserved. Where a state seeks to protect the interests of its producers, this is usually at the expense of the consumer. Thirdly, the economic interdependence of the constituent parts of the UK and of the UK with other states, particularly within the EU, is now an important constraint on the scope of economic policy of the UK Government. It would be even greater for a Scottish Government. It is likely that if a Scottish Government pursued industrial policies which diverged significantly from the policies of the rest of the UK, it would need to introduce controls to fence off the Scottish economy. The freedom to pursue an independent economic policy would impose significant costs on Scottish industry and on Scottish consumers.

\section{Financial Services}

The hostility of the Scottish financial sector to major alteration of the constitutional status quo is well known. The publication before the 1992 General Election of the Pieda study of the Scottish economy (Bell Lawrie White 1992) generated considerable political controversy. In particular the suggestion that Scottish quoted and investment-oriented businesses had considered moving their head offices out of Scotland in response to devolution or independence attracted comment.

The economist, Professor Andrew Bain, examines the nature, scale and significance of the Scottish financial sector, which employs about 77,000 people and is a major service export industry. He analyses the problems which independence and the creation of a separate currency would create. The banks and life assurance companies would be likely to face significant transitional problems before, during and after the creation of a separate currency. The most important market of the Scottish life assurance companies is the rest of the UK. Independence would therefore be likely to cause permanent damage to the Scottish life assurance industry through the loss of new business from England. 
To avoid this risk of permanent damage, it would be in the interest of some companies to shift their country of incorporation to England. Some investment fund managers would be likely to face similar, though less severe, problems. The threat of disadvantageous tax rates, whether or not they eventuated, could also cause at least temporary problems for Scottish life assurance companies. Any move towards higher rates of personal taxation in Scotland would have an adverse impact on the operating costs of Scottish fund managers. Even the possibility of this occurring might affect their ability to attract to Scotland qualified employees who could obtain employment elsewhere.

Of these problems, the threat of permanent damage to major Scottish institutions' access to the English market is the most serious. Scotland's financial institutions depend on the continued economic integration of the UK and are likely to remain hostile to any political initiative which threatens that integrity. Accordingly they might be hostile even to devolution, if it were seen as a prelude to independence rather than as part of a UK-wide decentralisation.

It appears therefore that in the present structure of the EU independence is likely to impose heavy costs both on Scottish industry and on Scotland's financial sector. If the EU achieves monetary union, some of the serious economic problems which independence would pose might be avoided. But there would be little scope for any Member State - and particularly a small Member State - to pursue within the monetary union a significantly independent economic policy. This causes an economist to ask the question, 'Where is the benefit of independence?'.

\section{Economics}

Dr David King, an economist, examines the scope for a Scottish Government to pursue independent economic policies if Scotland remained within the EU. He argues that an independent Scotland would probably be admitted to the EU only if it agreed to participate in monetary union when that occurs. And when it does occur, he believes that all EU members will find it difficult to pursue independent economic policies. Indeed, this is the main reason that some elements of the Conservative party are so hostile to monetary union.

He begins by examining the performance of the Scottish economy and finds that Scotland is currently one of the more prosperous regions of the UK. He then examines the scope for independent economic policies under three categories, namely stabilisation (the regulation of demand to influence unemployment and inflation), redistribution and resource allocation.

It is notoriously difficult for any national government to pursue successful stabilisation policies. The recession which has afflicted most OECD countries vouches for the difficulty. The problems are greatest for small economies where imports and international capital flows are relatively important, especially if there are no controls over imports or capital flows. In such economies, any attempt to alter demand and domestic output by using fiscal or monetary policy may lead chiefly to a change in the level of imports. Moreover, there may be very little scope for setting independent interest rates and so very little scope for even attempting an independent monetary policy. An independent 
Scotland might seek to create some scope for an independent monetary policy by reimposing capital controls, but this is unlikely to be permitted by the EU. In any event that would threaten Scotland's financial sector. Alternatively, it might seek to raise demand by reducing the exchange rate of its currency. But Irish experience suggests that a policy of depreciation leads to increases in domestic prices.

The difficulties would be greatly compounded by monetary union. It is widely accepted that once that occurs, all EU members will be largely unable to pursue their own stabilisation policies. With monetary union, there will be a single European currency regulated by a central EU bank, so members will have no scope for independent monetary policies or exchange rate policies. The EU is already urging governments to limit their borrowing which in turn curtails fiscal policy.

A Scottish Government would be likely to have only limited scope for independent redistribution policies. Scotland will have close links with the rest of the UK and the EU. If a Scottish Government imposed higher taxes on its wealthier citizens to finance more generous transfers to the poor, the former might be tempted to vote with their feet and leave. Moreover, assuming that an independent Scotland signed up to the Maastricht treaty, it would find even more curbs on its independence.

In the field of resource allocation, King sees much more scope for independent policies. An independent Scotland could certainly adopt its own policies over the ownership and finance of the water industry and over public services such as education and health. But King wonders whether much of the control of these activities might not best be entrusted to smaller authorities within Scotland to bring decisions even closer to the people.

King's chief conclusion, then, is that, once monetary union has taken place within the EU, there will be little scope for independent stabilisation policies by any member government. To secure any substantial freedom of action, Scotland would have to secede from the EU as well as the UK. It is not clear how much support there would be for this within Scotland, especially now that most of the west European non-members of the EU seem set to join.

\section{International Relations}

Economic arguments are only one part of a range of arguments which are advanced for or against the Union. There may be circumstances in which even significant prejudice to a nation's economy is a price worth paying for a desired benefit from independence. Are there such benefits for Scotland?

One field which requires examination is that of international relations. It has been argued that Scottish interests would be advanced more successfully in international affairs if Scotland were independent. 'A small voice is better than no voice at all' (Scott 1992a: 44).

The former diplomat Sir John Thomson considers these arguments. He sets out three options available to Scotland, as an independent country within the EU; as an independent country outside the EU; and as a constituent nation of the UK. 
At present Scotland's voice may be heard on the international stage indirectly, mediated through the voice of the UK. No doubt as part of the UK, Scotland's interests require to be weighed up along with other UK interests. As a result on some occasions Scotland's interests will prevail and on others they must give way. But the UK is one of the larger Member States of, and is a substantial net contributor to the EU. It is also a country which for historical and other reasons has greater clout than the size of its economy would suggest. As a result the UK enjoys a much greater international influence than Scotland could aspire to.

A Scottish Government would require to establish a separate diplomatic service and defence forces for an independent Scotland and would incur significantly increased costs as a result. Independence would involve Scotland in negotiating a divorce from its larger and more powerful neighbour. Few divorces are amicable and Scotland would be in a relatively weak position in such negotiations. Further, it is likely that an independent Scotland would be involved in at least some negotiations in order to become a member of the EU in circumstances where the break-up of Member States within the EU might be seen as damaging to Europe and where Scotland would be only one of several small states seeking membership.

Scottish nationalists - drawing on and updating the ideas of Andrew Fletcher of Saltoun about three hundred years ago - have advanced the argument that Scotland could join with other small states within the EU to curb the power of the larger Member States. Thomson questions this view. On the one hand he doubts whether voters in Scotland favour much closer European integration any more than voters in other Member States. On the other hand he suggests that the smaller Member States, being geographically and economically disparate, will not find it easy to combine as a bloc within the EU. As the number of members grows, so the relative importance of each of the small states will decrease, while the influence of the five major states will remain the same or increase.

He concludes that it would probably not be sensible for Scotland to opt for independence outside the EU. Independence within the EU means giving up at least as much sovereignty and control as is involved already in membership of the UK. In terms of international relations, although Scotland would have a vote in the EU, it could expect the Scottish voice to be less influential than if expressed through the UK. He also notes the likelihood of serious divisions within the Scottish nation in the process of arranging for independence whether within or outwith the EU. On balance he concludes that independence is likely to be costly for Scotland's international relations while simultaneously resulting in less effective representation of its interests.

\section{Historical Arguments}

It is necessary to consider other supposed benefits of independence for Scotland. One such benefit is the preservation and advancement of Scottish culture. None of the contributors to this book challenge the view that Scotland is a 
nation and that there are features of Scottish culture which are distinct from the cultures of the other parts of the UK. It is, however, notoriously difficult to determine what we mean by nationality, culture and identity in Scotland or anywhere else.

Nationalism has been defined as 'a political movement which seeks to attain and defend an objective which we may call national integrity' (Minogue 1967: 25). National integrity, like national identity, is difficult to define. Nationalists often tend to exaggerate not only the distinctiveness but also the coherence of the national culture they seek to protect. In order to give political content to their perception of national identity, nationalists frequently adopt a tendentious portrayal of the past. In his celebrated, and unsympathetic, study of nationalism Eric Hobsbawm (1990: 12) put the point more forcefully:

Nationalism required too much belief in what is patently not so ... Getting its history wrong is part of being a nation.

In Scotland, the argument is often advanced that independence is necessary to preserve Scottish culture and Scottish identity from the elephantine weight of English culture. (See for example Scott 1991: 49-76).

History plays a central role in the debate in this field. The next three essays, by the historians Professor Roy Campbell and Dr John Morrill and by the constitutional lawyer Professor Colin Munro, seek to set the Union in its historical context and in so doing call into question some of the historical arguments which have been advanced in favour of independence.

Although there are clear differences in the traditions of Scotland and England, there were close ties between the two countries from at latest the middle ages. The Anglo-Norman aristocracy played an important role in the establishment of the Scottish kingdom. Recent historical research has shown that it is essential to an understanding of politics and society in the medieval British Isles to appreciate the close links of the aristocracies of England and Scotland in the formative years of both kingdoms. These links included ties of marriage, extensive land holdings in both kingdoms and in France, and connections with more than one royal court. Davies (1988) and Frame (1990) have argued persuasively that the strength of the royal and noble heritages across the boundaries within the British Isles created a common culture in the four medieval cores in lowland England, lowland Scotland, the Englishries of Wales and the Pale in Ireland. Each nation's history should be seen in a British context. The common law of Scotland in the middle ages involved a, no doubt discriminating, borrowing and adaptation of Anglo-Norman law from the successful English monarchy (MacQueen 1993; Sellar 1988). Further as Morrill points out, lowland Scotland, the heartland of the medieval and early modern kingdom, in part drew its language, social norms and religious culture from Normandy.

The Union was preceded by a long process of assimilation of Scotland and England. The dynastic ties forged in the sixteenth century led to the Union of the Crowns of 1603. Of central importance was the Reformation. It was not just a desire to escape from French ambitions to colonise Scotland but shared protestantism which caused Scottish politicians to turn to England in the 
mid-sixteenth century (Donaldson 1985). Protestantism also led directly to the King James Bible. Modern studies of nationalism (Anderson 1991; Hobsbawm 1990) have emphasised the importance of a common language and in particular the written word in the development of a national identity. The Bible written in English played a central role in the creation of a British culture.

The Union of the Crowns did not prove a satisfactory settlement of AngloScottish relations. There were disputes over religion until the two protestant kingdoms agreed to differ on the form of Church government in the revolution settlement of 1689. On the economic front the Scottish Government found it impossible to pursue successfully an independent economic policy against the interests of the Westminster Parliament and the City of London. The Union of 1707 was agreed upon as a remedy for long-standing problems in the relations between Scotland and England as well as the short-term need to secure an agreed succession to the throne. While the English negotiators may have insisted on an incorporating union, it was not the English but the Scots, including even the covenanting leadership, who had attempted repeatedly in the seventeenth century to put Scotland's relationship with its larger neighbour on a more established and secure basis. Further Scotland obtained the much-needed access to the English and colonial markets which contributed greatly to its industrial success within the Union.

The Union was not an attempt to achieve a complete assimilation of Scotland with England. Munro discusses the continuance of Scottish national identity in the Church, the law and civil society. Each changed over time. The Kirk played a central role in Scottish identity until the Disruption of 1843, which was 'the death of the godly vision', and increasing secularization weakened its role (Storrar 1990). Scots law has retained much of its independence. Harmonisation with English law has occurred principally in the field of commercial law and frequently in response to initiatives not from London but from influential Scots lawyers and businessmen (Rodger 1992). Harmonisation of commercial law is now pursued by and within the EU. Further, while the Union gave rise to some further cultural assimilation, a sense of Scottish identity remains strong. In reality Queen Anne's 'entire and perfect Union' was neither sought nor achieved. The qualified nature of the Union has preserved in being institutions which tend to approach problems principally or solely from a Scottish standpoint.

Campbell attributes the increasing stress on Scottish distinctiveness and the relative economic decline of the UK in the twentieth century as causes of increasing political introversion in Scotland. This isolationism, he warns, threatens the Union and may lead to a result which most people in Scotland do not want.

National sentiment often rests on a belief that a people within a defined geographical area form a community (Seton Watson 1977: 5). However, a nation is at best an extremely abstract kind of community; even a small nation is too large and contains too diverse a population to be anything other than 'an imagined political community' (Anderson 1991: 6).

Some of the stories which have underpinned national sentiment to create this imagined political community are simply myths. Such myths may either 
be historically untrue (such as the Swiss story of William Tell) or else an idealisation of fact. Other stories are mere assertions which have an unreliable historical basis or are not a balanced assessment of historical fact. One example of the latter is the presentation of the Union as the triumph of a long-pursued English scheme to dominate Scotland. Morrill's paper provides a refutation of this view.

Another is the assertion that the Union was achieved principally through bribery and intimidation. This assertion has a long pedigree:

We're bought and sold for English gold -

Such a parcel of rogues in a nation!

It survives in one of Paul H Scott's modern nationalist booklets (Scott 1992a: 23), although it is qualified in his historical study of Andrew Fletcher and the Union (Scott 1992b). The Scottish politicians who supported the Union and risked the anger of the mob were not selling their birthright for a mess of pottage (Speck 1994: ch 6). The reality behind the Union was a combination of, on the one hand, the pursuit of Scottish economic interests and the benefits of political stability, and, on the other, political manipulation and Government patronage. The latter was part and parcel of politics at that time, and at other times.

Those who favour independence often assert that, as a multi-nation state, the UK is an anomaly (Scott 1992a: 27). This is unfounded in fact. On the contrary, many modern states contain several nations and several cultures. France and Spain are clear examples, with Brittany and Catalonia among others being nations within a larger state. Italy is a state which was created by a political movement before an Italian national identity had been developed among its people. 'We have made Italy, now we have to make Italians' were the words of Massimo d'Azeglio (Seton Watson 1977: 107). Germany has components such as Saxony and Bavaria with a long history of distinctive identity. Accordingly it is truer to say that the UK as a multi-nation state is an example of the European norm.

That Scottish culture is distinctive and valuable is not in dispute. However, the degree of distinctiveness may often be overstated. George Davie's (1961) influential thesis on Scottish university education highlighted the role of a broad philosophical education in the Scottish universities at the time of the Scottish Enlightenment and in the early nineteenth century. He lamented the anglicisation of the Scottish universities from the mid-nineteenth century onwards and the development of a more specialised and less philosophical education. His works have contributed to the belief that Scotland formerly possessed an education system which was open to children of all classes and permitted social mobility between the classes. However, more recent historical research into education and opportunity in Victorian Scotland strongly suggests that any supposed golden age of opportunity by educational advancement never existed (Anderson 1989). By the mid-nineteenth century Scotland's economic development required, not a broadly-based philosophical education, but one which gave due weight to modern science and mathematics (Campbell 1980: 41-52). Whatever the reality, the idea of such a 
philosophical education was by then out-dated. Further the belief that there was significantly greater social mobility in Scotland than in England, the myth of the 'lad o' pairts', has on closer examination been found to be overstated. While social advancement through education may have been available to a wider range of the middle classes in Scotland than in England, opportunities for advancement from the working classes remained few in both countries.

The structure of Scottish society is strikingly similiar to that of other parts of Britain. This may not be surprising as Scotland is, like other parts of the UK, an advanced industrial society. Scotland had in the later nineteenth century, and has retained, a similar profile of industrial employment to Britain as a whole, a similar occupational structure and a similar proportion of women in employment. Its patterns of social class and social mobility are shared with other parts of Britain (McCrone 1992: chs 3 and 4). Accordingly neither social nor economic structure provides clear support for Scotland's egalitarian myth, which may be more a social ethos than an analysis of fact. It is certainly not a convincing explanation for the divergence of voting behaviour between Scotland and the rest of the UK in recent years.

\section{Constitutional Law}

As Munro points out in his essay on Scotland's constitutional position, the Union which created the British state was not an attempt to create a homogeneous British nation. The similarities between Scotland and the rest of the UK are not the result of any grand policy of assimilation but are largely the product of long-established ties, piecemeal initiatives and circumstance.

If the creators of the Union legislation intended to make at least some of its provisions unalterable laws, they did not succeed. Subsequent parliamentary legislation has significantly altered, and often for the better, the provisions of the Treaty of Union. Further while the Scottish Courts have been equivocal in their pronouncements on the status of the Treaty they have never held a later statutory provision invalid on the ground that it breached one of its articles. This may be contrasted with the attitude of the British Courts to UK legislation within the sphere of competence of the EU, where UK legislation has been declared inapplicable when it contravened European Community law.

The relationship of Scotland with the rest of the UK has therefore not been secured by any 'Basic Law' or other special constitutional provision. Nevertheless, Munro argues that the nationhood of Scotland within the UK has received constitutional recognition in a number of ways. First, the preservation of Scots law as a separate legal system has upheld a distinctive symbol of national identity. Secondly, within Parliament there has been a practice of introducing separate legislation for Scotland in relation to certain matters, and there are separate legislative procedures for such Scottish measures. However, shortage of Parliamentary time has hampered the enactment of Scottish provisions. This has given rise to criticism, which is not without foundation, of failure to reform Scots law by implementing the proposals of the Scottish 
Law Commission. Thirdly, the high degree of administrative devolution introduced since the late nineteenth century has contributed to Scotland enjoying a higher expenditure per capita than other parts of Great Britain. Further there has remained in Scotland a distinctive civil society involving the Kirk, the legal profession, the separate education system, a Scotland-oriented media and distinctive architectural traditions.

Government in Britain has continued to undergo reform. The intensification of government activity has been followed by the extension of judicial supervision of its decision-making. The courts have since the 1940s developed new judicial review doctrines. The 1970s and 1980s saw the introduction of quicker court procedures for judicial review in both Scotland and England. This has encouraged the Civil Service to be aware of the scope for judicial challenge to its actings and in a pamphlet entitled The judge over your shoulder (Cabinet Office 1987) to instruct its officials on the constraints imposed on them by the law. If government cannot be made to be good, it can at least be made to follow proper procedure; and accountability is thereby increased.

The contributors to this book do not dispute that further reform is needed. Rolling back the frontiers of the state in the 1980s had some paradoxical results. For example, changes to the structure and finance of local government led, in some respects at least, to centralisation of power and decision-making in Whitehall and associated quangos. There remains scope for further reform of government without breaking up Britain or destroying the integrity of the UK economy. Several contributors argue for greater decentralisation throughout the UK. Many of the benefits, for which advocates of independence argue, may be achieved by less radical measures. UK-wide decentralisation, a strengthening of local government and reform of parliamentary procedures to ensure adequate time for Scottish measures could achieve much.

\section{Scottish Culture and British Culture}

The fact that a considerable majority of Scottish voters in General Elections has continued to vote for the UK parties and has not favoured the option of independence may indicate not only a belief that the British State can meet its demands but also an awareness of the cultural ties which in recent years have been overshadowed by an emphasis on our cultural distinctiveness. In the final essay, the author and journalist Allan Massie examines the cultural community which has grown up between Scotland and England over many centuries. This community is not simply a product of the Union. The Union has built on what Scotland and England already had in common.

Contrary to what is often asserted by Scottish nationalists, Scotland was not and is not 'more European' than England. In the middle ages Scotland and England shared in the common feudal culture of Western Europe. Both countries have long had strong cultural links with the Continent. Of the several strands in Scottish culture the Celtic strain in the highlands is the most distinct from that of England. Yet this separates highland Scotland as much from 
Europe as from England. It has also separated the highlands from the lowlands in Scotland since at least the fourteenth century. The Scots language, which became the official language of administration in late medieval Scotland, was a brand of English having developed out of North English. There was little difference between the language spoken on either side of the Border in this period.

Cultural ties were greatly strengthened when the Scottish kingdom shifted its political alliance from France to England at the Reformation. The close links with England, which were created by the Reformation, had a profound effect on Scottish culture for three hundred years. These developments formed the cultural backdrop to and help explain the attempts in the seventeenth century, especially by leading Scottish politicians, to create a political structure in Britain which would secure the co-operation of England and Scotland in the longer term.

Following the Union of 1707 the main Scottish institutions were left in Scottish hands. At the same time a process of assimilation occurred whereby leading literary figures from different parts of Britain exercised a profound influence on each other. Massie points to major figures such as $\mathrm{Dr}$ John Arbuthnott and James Thomson as evidence of a community of culture in eighteenth-century Britain. Even the ersatz Gaelic culture of Macpherson's 'Ossian' appealed to a taste for Celtic mythology which was already well established throughout Britain. On a higher plane there were close ties between eighteenth-century philosophers and historians such as Smith, Hume and Gibbon.

The French Revolution and the resulting disruption on the Continent strengthened the idea of Britain and British culture. Burke and Macaulay, respectively Irish and Scottish by descent, were both British writers. In the nineteenth century and afterwards the cross-fertilisation of cultures continued with Scots writers such as Scott, Carlyle and Stevenson having easily as much influence on English culture as English writers had on Scotland. The role of the Scots in the BBC in the twentieth century, and in particular Lord Reith, is well known. Migration in both directions across the border has strengthened the cultural community.

This cultural community has developed and exists independent of the political organisation of the British State. Professor Linda Colley (1992: 374-75) has argued persuasively that the forces which shaped British political identity in the eighteenth century, namely protestantism, the external threat posed by France and the commercial opportunities of Empire, have either declined in influence or ceased to operate and that a substantial re-thinking of what it is to be British is needed. She sees Great Britain as an invented nation superimposed on much older alignments and loyalties. However, it is important to realise two points in considering this argument. The older alignments and loyalties of which she speaks included, as Massie argues, a substantial community of culture within Britain, regardless of political structure. Also the component parts of Britain, including Scotland, have themselves changed irrevocably since the Union. The Kirk, which played a central role in Scottish life between the sixteenth and nineteenth centuries, has suffered a calamitous 
loss of influence. In all parts of Britain, secularisation has altered fundamentally the nature of our society, and probably nowhere more than in Scotland, which has been described as 'part of the modern, agnostic, consumer, capitalist society, facing problems of resource shortage, and potential nuclear extinction' (Smout 1977: 11). The uncertain search for a role and for a new identity is thus not confined to apologists for the British State but affects those who, with intellectual honesty, argue for a return to Welshness or Scottishness.

\section{Conclusion}

Economic arguments which loomed large at the time of the Union remain an important part of the Scottish debate. Scottish nationalists have not as yet, put forward a convincing economic case for separation. In particular, reliance on the single European market does not give enough weight to the many barriers to trade within that market. Nor does it deal with the problem that, after independence, many Scottish products, in particular financial products, would be perceived as foreign in their most important markets, viz the rest of Britain.

It is likely that the integration of the European economy and the harmonisation of the commercial laws of Member States of the EU will continue, even if only faltering progress is made towards political integration. In that context it is difficult to see how the costs - both financial and otherwise - involved in separation from the UK to create a small nation state within the EU can be justified on economic grounds.

Further, it is far from self-evident that the pursuit of independence is the road to a better society in Scotland. Tolerance and pluralism are widely perceived as virtues in the Western world. In this book it is argued that as a general rule a multi-nation state is more likely to secure tolerance and pluralistic democracy than a nation state where government is legitimated by nationalism. That is not to say - as some have done - that nationalism is necessarily evil. In a recent David Hume Institute paper Professor Neil MacCormick (1994) has argued for a liberal nationalism which respects pluralism and protects minorities. Nationalism, he argues, may be compatible with individualism as individuals have their identity in the context of a particular society and culture in which they live. However he recognises, as the history of the later twentieth century so amply demonstrates, that it is profoundly difficult to secure acceptance only of liberal nationalist principles (MacCormick 1994: 95).

It is not a sufficient answer - as others would have it - to the critics of nationalism to say that it is not nationalism but only imperialism - where one nation seeks to assert its power over another - which is a moral evil. That argument ignores - as MacCormick does not - the internally divisive tendency in many nationalist movements, through their emphasis on what is allegedly distinct in their culture, to deny the heterogeneous nature of their society and that part of their identity which is shared with their neighbours. Such movements tend to exclude or disregard the interests of those of their citizens who 
perceive themselves in terms of the shared identity or who have a cultural identity different from the politically favoured norm. The example of the Slovak Republic and its Magyar minority is one of many.

In Scotland, nationalism has been blighted by anti-English sentiment despite the worthy efforts of its political leadership. The contributors to this book challenge several of the beliefs which are prevalent in Scottish nationalist writing. One which is not examined but which is worthy of study is the simplistic contrast drawn between characteristics which are said to be Scottish and those which are attributed to the English. Not only is Scottishness an ill-defined concept but also there is a failure when speaking of 'the English' to appreciate the heterogeneous nature of English society. The stereotype of many Scottish criticisms is a member of the south-eastern metropolitan elite. There is a failure to appreciate the geographical diversity of English culture and society and a failure to recognise how much lowland Scottish society and culture have in common in particular with the north of England. While it may be gratifying to compare ourselves with a demonised stereotype, it does little to reveal the truth.

If voters in Scotland seek to alter fundamentally the structure of their government, it is important that they do so with their eyes open not only to the benefits but also to the costs - and not just the economic costs. And it is essential that those who campaign for or against such radical change should present the options in an open way. In a recent profile of Nelson Mandela in The Independent on Sunday (1 May 1994) Neal Ascherson stated:

Mandela does have some of the qualities of Thomas Masaryk, who brought the Czechs and Slovaks to independence in 1918. There is the same fanatical attachment to truth, as if freedom achieved by lies, bombast and deceit were not worth having.

If we have that attachment to truth, may we not recognise that there are many Scots - perhaps the majority - who feel strongly about Scotland as a nation, but who consider that it can best express itself within the UK? May it not be that those who pursue independence overlook the divisiveness of that policy within Scotland, and underestimate the bitterness which a break from the rest of Britain would create?

What we have in common with people from other parts of Britain far outweighs our differences. The continuing process of European integration is creating opportunities for the Member States of the EU to re-organise the distribution of political power within their borders. It is not clear whether and to what extent this will lead to constitutional change in Britain. However a political structure which recognises our plural identity - Scottish, British and European - is one which is likely to foster liberalism and pluralist democracy. A nationalism which rests on a partial view of our history and identity, far from emancipating, may diminish us. 
